\title{
Everyday Urban Life: Genealogy and Journal of Actors' Body in the Viral City
}

https://doi.org/10.21814/uminho.ed.51.3

Pedro Andrade

Centro de Estudos de Comunicação e Sociedade, Instituto de Ciências Sociais, Universidade do Minho, Braga, Portugal https://orcid.org/0000-0003-4550-0562 pjoandrade@gmail.com

\section{Abstract}

This text aims to understand how the COVID-19 pandemic influences contemporary society, particularly in its most basic configurations, the daily urban life of social agents and their urban bodies, within the global city and, more recently, inside the viral city. To this purpose, a synthesis of part of an ongoing project is presented here, in two dimensions of everyday life: daily times in conjunction with everyday spaces. In the diachronic and historical axis of reality, transformed today into a viral society, it is possible to distinguish the following daily life configurations: cyclical everyday, routine everyday, exceptional every day and dialogical every day. In the synchronic axis, and particularly in contemporaneity, 10 sociological theses are proposed here to try to decipher some of the main processes where the impact of COVID-19 on the coeval urban fabric and the body of its actors is most felt. Finally, the author suggests some possible alternative strategies to the pandemic in the context of today's viral daily life. However, these are only very general lines of sociological reflection, intended only to help define future courses of action for practical solutions, which are still unclear. That may be done within the framework of reconstruction of a healthier and more creative urban daily life for all citizens of the planet.

\section{Keywords}

COVID-19, daily urban life, viral city, viral everyday, viral society 


\section{Introduction}

\section{The Socio-City in the Viral Society and the Viral City}

This text essentially presents some theoretical reflections carried out within the ongoing urban sociology project on the contemporary city, particularly the urban fabric confined and transformed by the COVID-19 pandemic. The respective fieldwork is only indicated here through some photographs taken in 2020, after the COVID-19 outbreak. Such direct observation images are intended to raise awareness of the coronavirus pandemic's ubiquity in the social fabric, witnessing some of its manifestations and effects in daily life, within the context of the economic and cultural spheres, or in terms of citizenship regarding confinement. Therefore, it is not the presentation of the ongoing fieldwork which will be exposed on another occasion. Differently, these illustrations work only in terms of "paratext", as Gérard Genette (2010) puts it. In other words, such images work as an introduction, an "aperitif" or a "business card" for a clearer and more sensitive reading of the central theme of the text, that is, everyday urban life, which signifies an intermediate dimension: the daily living that synthesises the spheres mentioned above, or others.

The city has been the subject of varied sociological problematisation since the beginning of sociology. Nevertheless, the debate about the effects of the coronavirus on urban life is naturally still in its infancy, given the unprecedented nature of such a social process. For this discussion, it is necessary to contextualise the city in its economic and sanitary, corporal and cultural, geopolitical and diplomatic, ecological and regional aspects, and so forth. Therefore, this sociological study aims to dialogue with different sensitivities inside scientific, technological and artistic communities.

The stupefaction in what regards COVID-19 appears immediately in the unprecedented nature of the current pandemic, which has transformed all spheres of our individual or societal life and bodies. Therefore, it is necessary to adopt a posture of deep sociological imagination to understand such a novelty from new sociological concepts that can translate this original social texture scientifically and from a citizen's point of view.

The first and most general emerging phenomenon that appears to arise is a kind of viral society, which includes, among other processes, a viral city and viral bodies of social actors. Such a virulent society constitutes a social paradigm founded on recent changes in the social sectoral spheres. For 


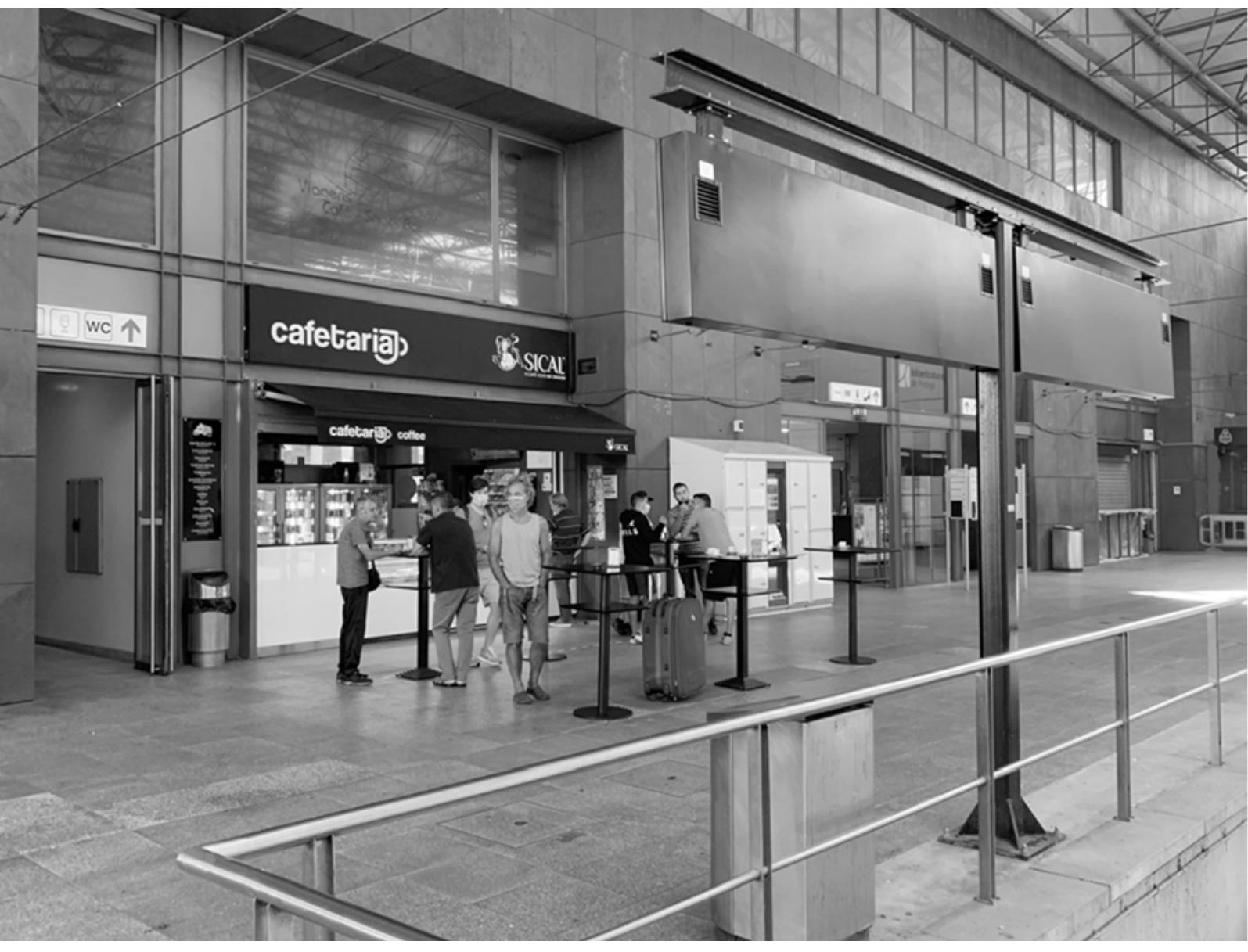

Figure 1 The viral economy in the transport and catering sector: usage of masks at Braga train station and bar.

Credits. Pedro Andrade

example, viral economies and technologies, based on fragilities and global economic crises of capitalism and the world economy, are motivated by computer viruses and, increasingly, by biological viruses. Among the sectors affected are transport, restaurants, public health, the tourism and hotel industries, or the cultural industry of book publishing.

Some illustrations of this socioeconomic situation's impact on the daily life of public spaces in cities are expressed by the usage of masks, for example, 


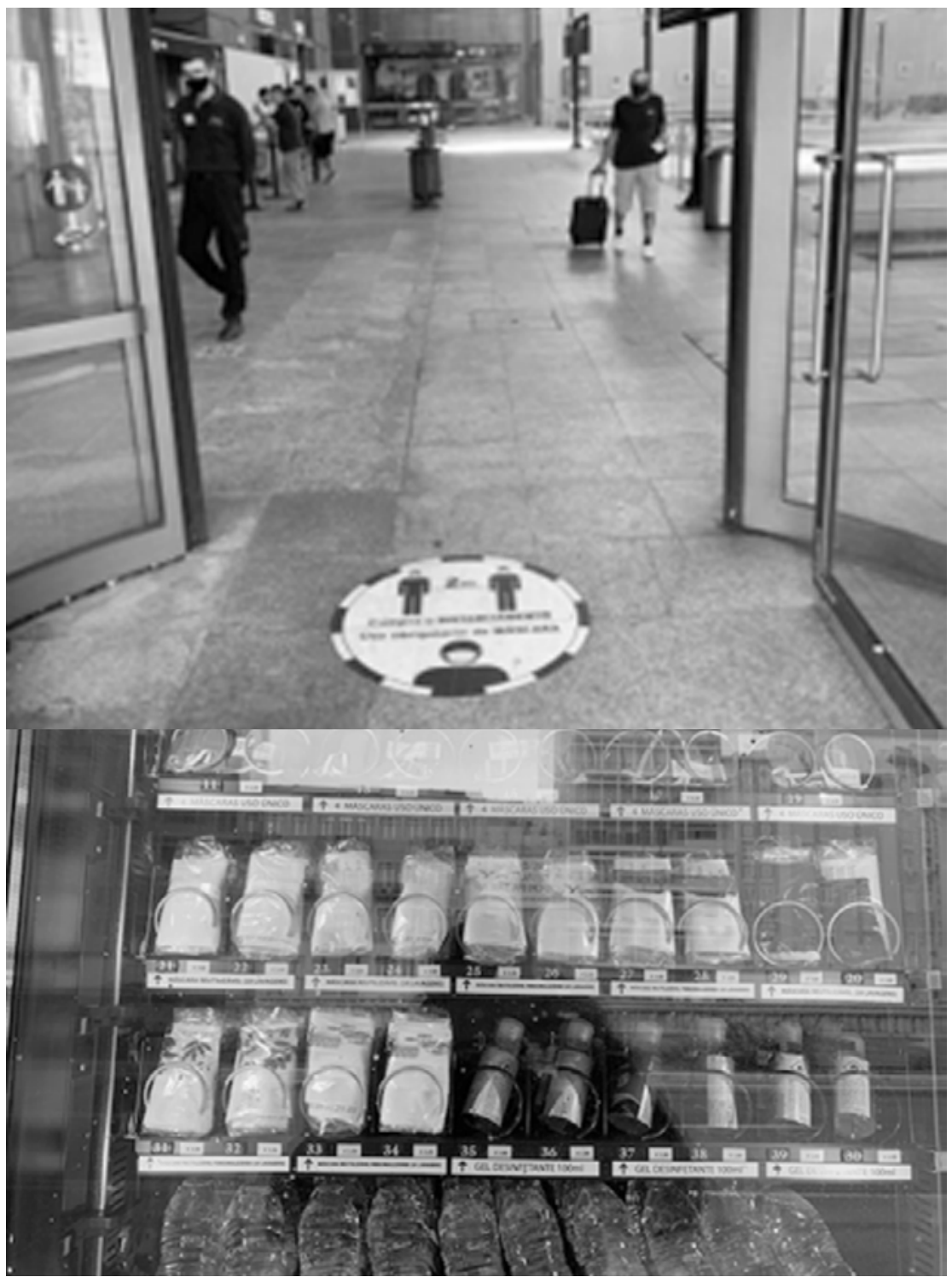

Figure 2 The viral economy in the transport and catering sector: health warning at Braga train station entrance. Credits. Pedro Andrade

Figure 3 The viral economy in public health: masks and drinks vending machine, in Lisbon. Credits. Pedro Andrade 


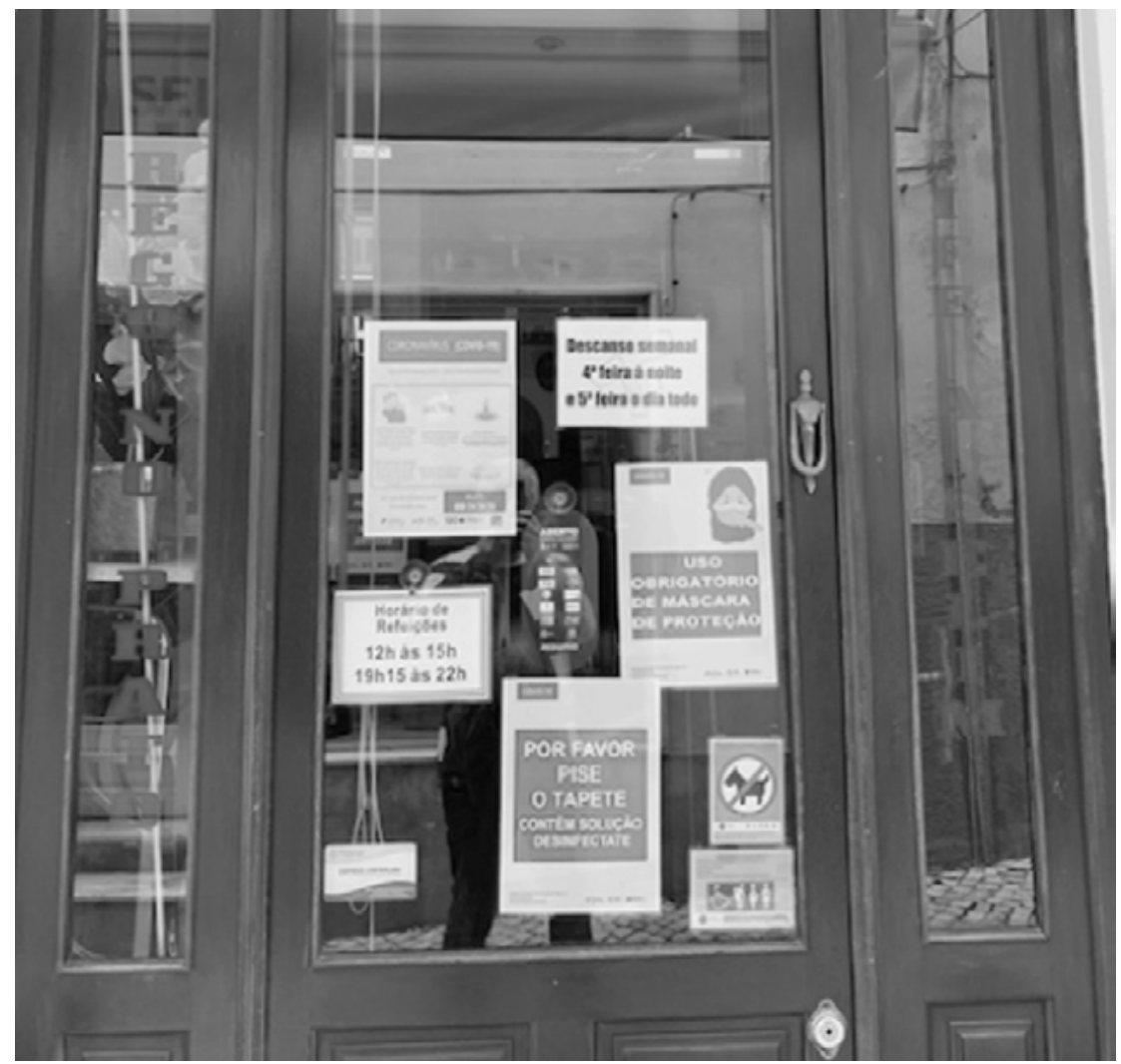

Figure 4 The viral economy in commercial advertising within restaurants, on COVID-19 awareness, Lisbon.

Credits. Pedro Andrade

at the Braga train station and the bar (Figure 1), or the health warning at its entrance, on September 5, 2020 (Figure 2).

Other daily manifestations in this sphere of the viral economy of public health are the mask and beverage purchase machines, at Lisbon, December 16, 2020 (Figure 3), as well as commercial advertising in restaurants about COVID-19 awareness, here patent on October 3, 2020, Lisbon (Figure 4).

In the tourism sector, observe the sanitary control during trips on moliceiro boats, Aveiro, on August 9, 2020 (see Figure 5), or, in the hotel industry, prevention regarding confinement in the lobby of a hotel, at Caldas da Rainha, October 3, 2020 (Figure 6). 


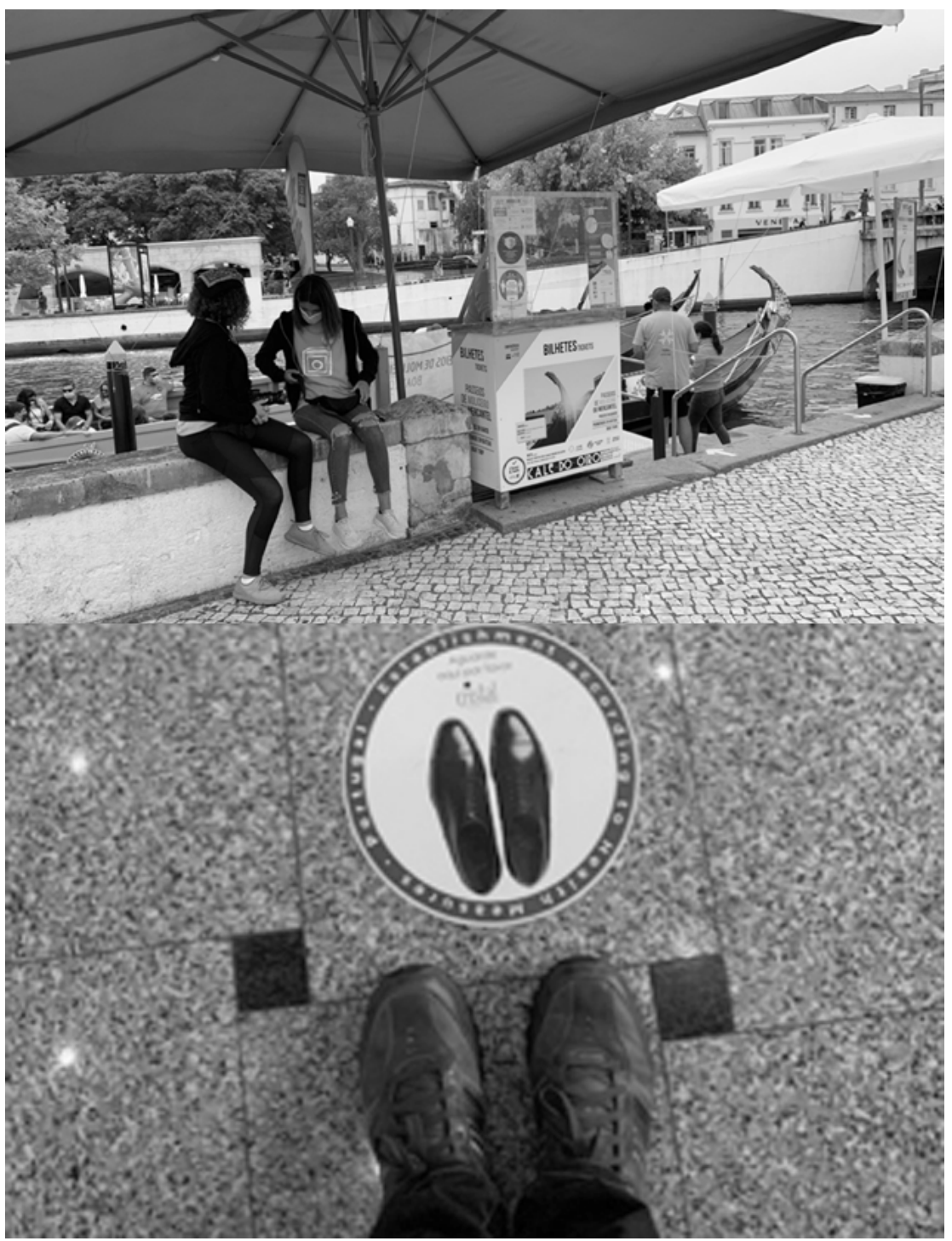

Figure 5 The viral economy in the tourism sector: health control during trips on moliceiro boats, Aveiro.

Credits. Pedro Andrade

Figure 6 The viral economy in the hotel industry: confinement in a hotel lobby, Caldas da Rainha.

Credits. Pedro Andrade 


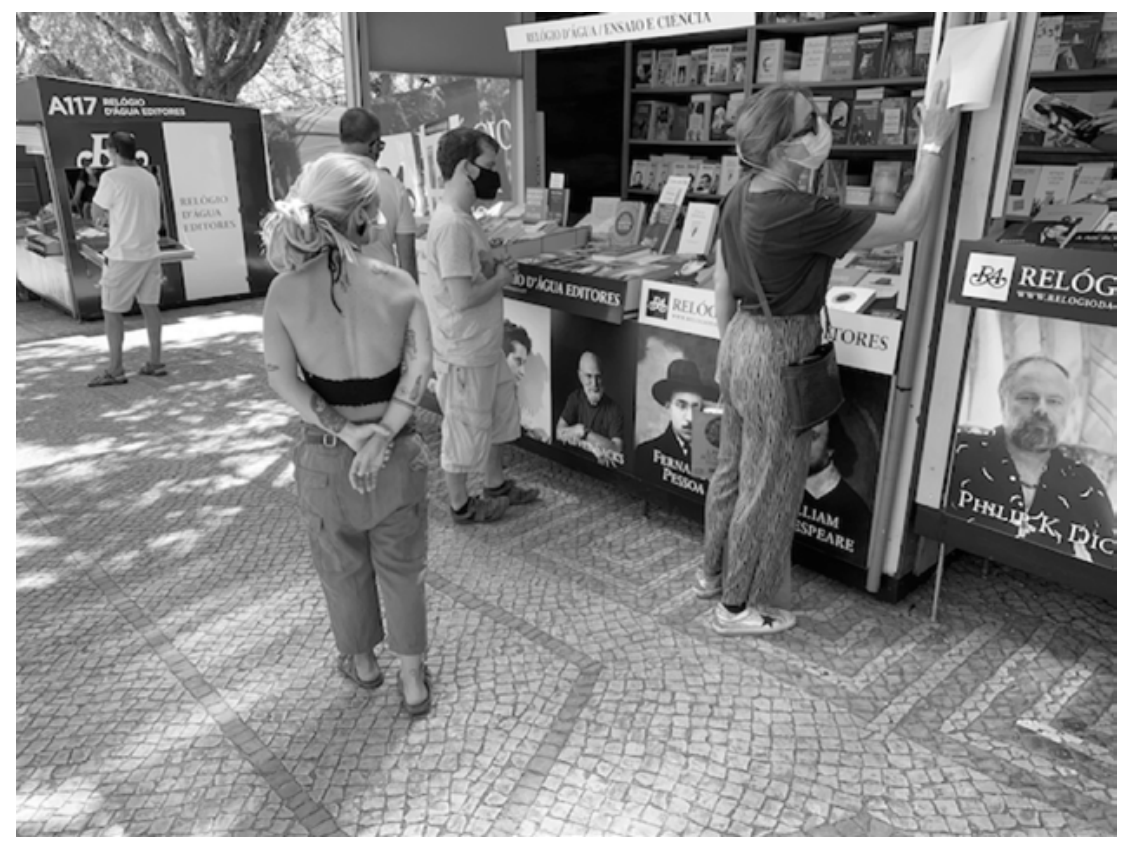

Figure 7 Viral cultural economy in the publishing sector: mask usage at the Lisbon book fair. Credits. Pedro Andrade

Likewise, the effects of the crisis were felt in the viral cultural economy within the publishing sector: the access to the reading public was conditioned by mask usage, at the Lisbon Book Fair, on August 30, 2020 (Figure 7).

For its part, viral policies mean the possibility that certain States, institutions, organisations, associations, and other social agents belonging to institutional powers or counterpowers either warn of the dangers of pandemics in the collective space to raise awareness of citizens for responsible social behaviours or exercise social criticism of health policies. In turn, viral politicians use different viruses as weapons of local or global threat, aggression or surveillance.

Particularly, within the social field of viral citizenship, inside the various waves of the pandemic, several strategies have emerged from multiple social and institutional actors, for example, in terms of awareness campaigns, the public health risks by the State (National Health Service, National Health Service-General Directorate of Health, etc.). The everyday public space witnesses some of these initiatives, through placards with warning 


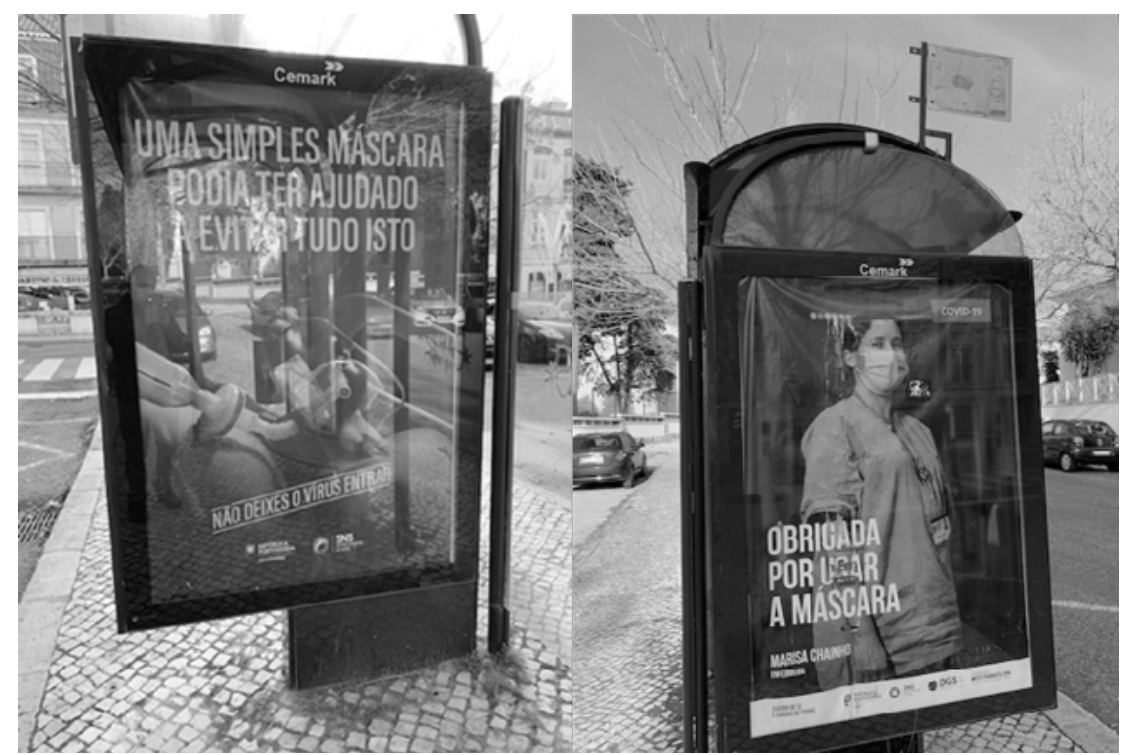

Figure 8 Viral policy in the awareness campaign by the State and National Health Service and the General Directorate of Health, for Citizenship in Public Health, in Lisbon.

Credits. Pedro Andrade

Figure 9 Viral policies through social legitimation of public health heroes, by the National Health Service and the General Directorate of Health, in Lisbon.

Credits. Pedro Andrade

messages about the consequences of negligence in the use of masks, in Lisbon, on December 25, 2020 (Figure 8); or honouring "pandemic heroes", such as doctors and nurses, in Lisbon, on December 25, 2020 (Figure 9), just before the third wave in January 2021.

As for viral cultures and cults, they connote the modalities of exercising science and the arts, or other knowledge and leisure, through virulent strategies, as in the case of certain digital social networks. That is, some of its users subscribe to the following cultural cult: the more followers and/or friends (or, in certain cases, the more enemies) they articulate or branch with a given social subject, individual or collective, the more cultural and cult value this subject accumulates and/or distributes across the social fabric. Some critical social actors deconstruct these cultural cults, such as teachers and researchers, visual arts artists, or other cultural professionals. For example, the use of a mask at congresses or other cultural events, as in 


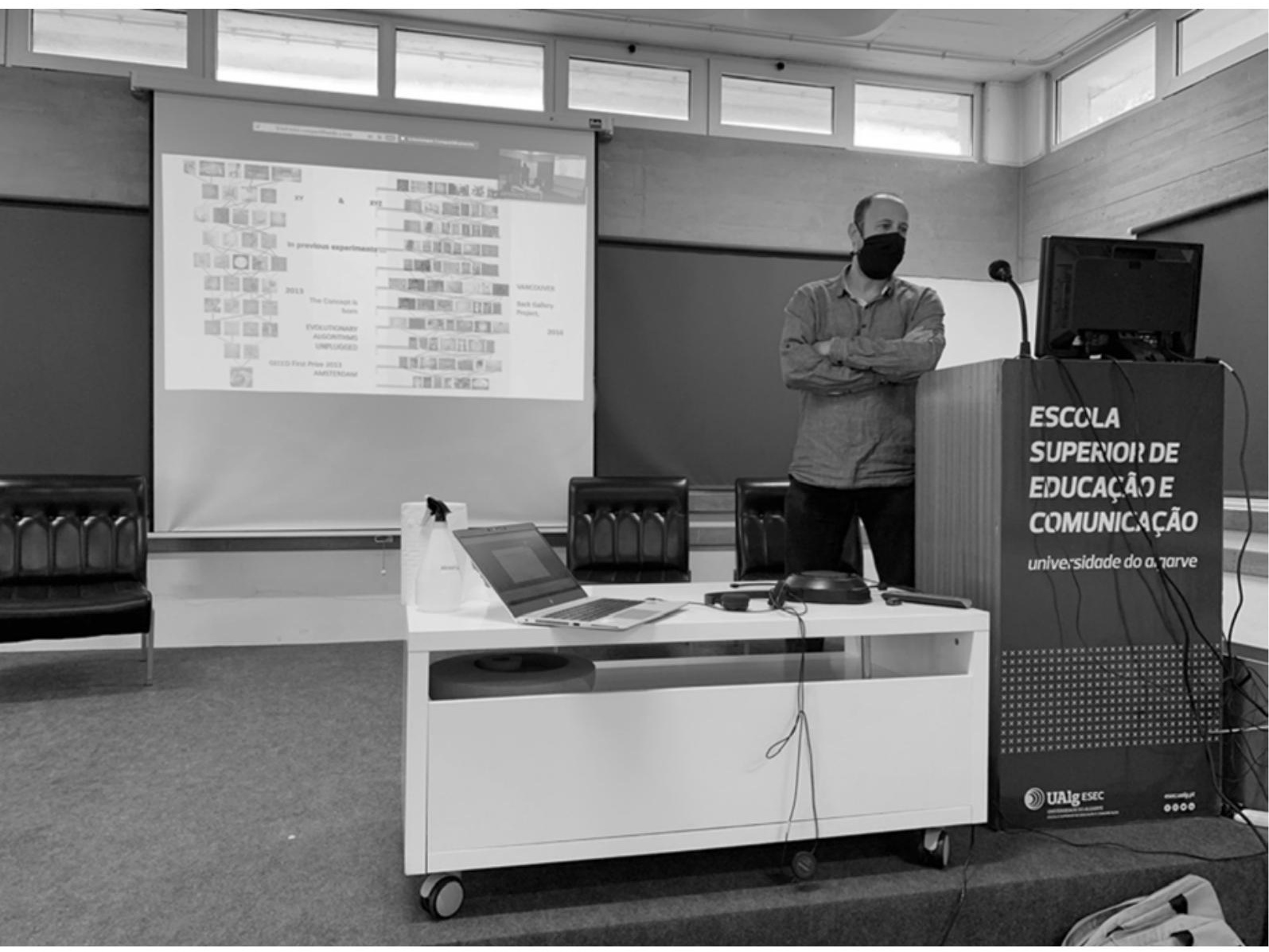

Figure 10 Viral culture and education through the use of a mask at a congress, Faro. Credits. Pedro Andrade

Faro, November 21, 2020 (Figure 10), radically changes the communication process of scientific research.

This pandemic situation of viral culture was also the object of economic and political criticism, through a work of art made by the author of the present text, in the form of an interactive ebook and app, and using disinfectant for its manipulation. This work was shown to the public at the exhibition "Sem Limites" (translation in English: "Without Limits"), curated by the association SOS Arte PT, and held at Fórum da Maia in Porto, on September 25, 2020 (Figure 11). 


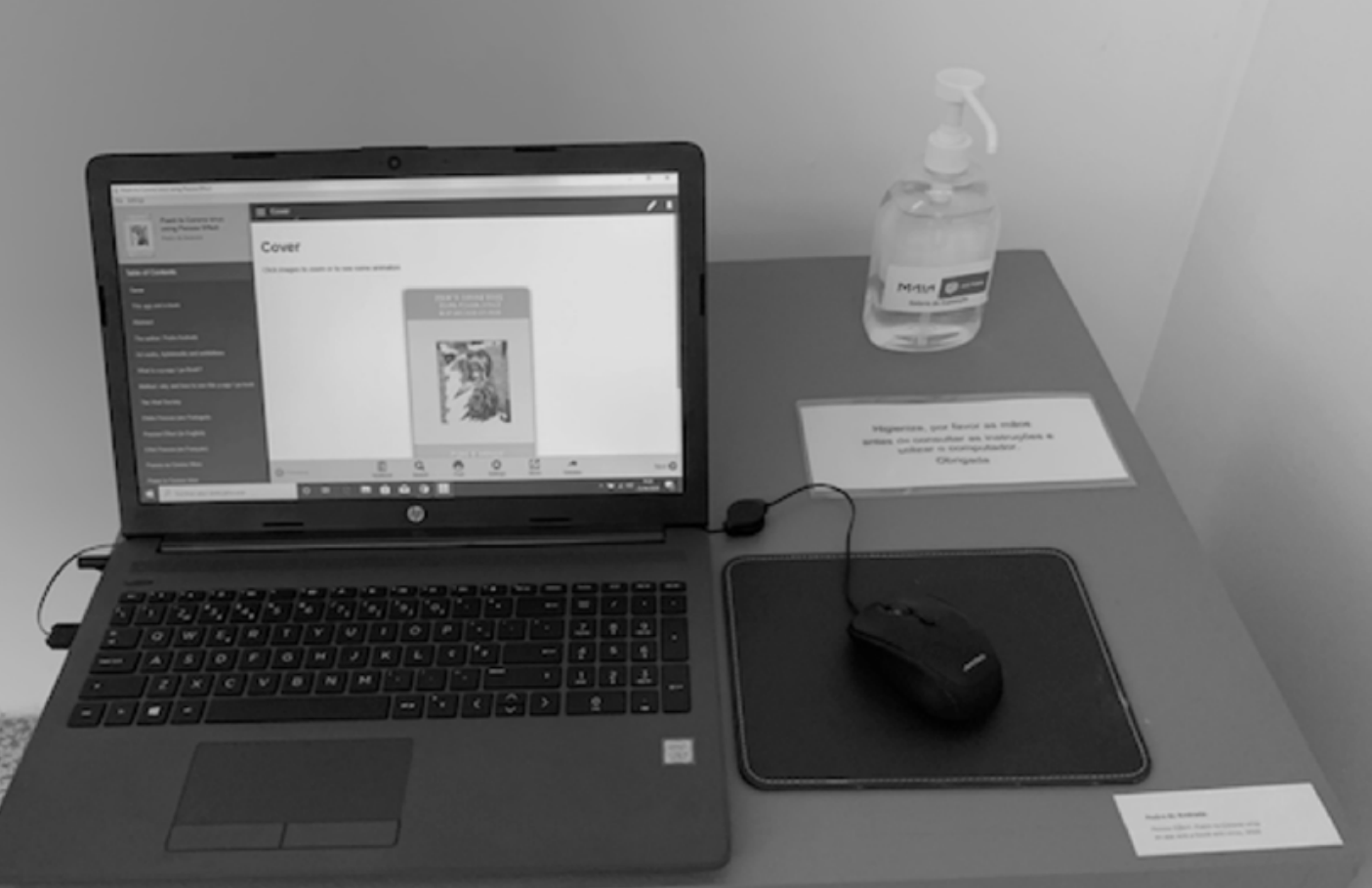

Figure 11 Viral culture in the exhibition "Sem Limites" curated by SOS Arte PT, visible through the use of disinfectant for the manipulation of an interactive work of art at Fórum da Maia, Porto. Credits. Pedro Andrade

\section{Sociological Problematization}

Under this social situation never seen before, to foster a sociological debate based on daily urban life in accelerated metamorphosis, it is essential to base ourselves on the following theoretical and empirical pillars, among others. Within the scope of the study shown here, a previous, current and synthetic discussion about the main theories on the city can be found in Andrade (2018c). In particular, among the urban spaces and times of the global city (Sassen, 2001), places of leisure or of "free time", apparently 
secondary, are unveiled after all as central loci of democratic citizenship and practices of knowledge, such as the places of public drinking (Andrade, 1991, 2018a). In addition, the city proves to be a major territory of emergency and convergence among public art, tourist activities and intercultural practices (Andrade, 2020b, 2020d, 2020e). In the last decades, within the network society, the notion of the city has changed even more, and its meaning unfolds today in multiple typologies, such as the creative city, the smart city, the city 3.0 and, even more recently, the viral city. The notion of city 3.0 underlying digital social networks, articulated with culture and tourism, can be consulted in Andrade (2018b, p. 226). Other definitions of such a current urban terminology are found in the writings cited in this text, and a brief synthesis of these concepts is visible in the Appendix.

Concerning the viral city, which will be the type of city discussed here in more detail, this concept means, among other connotations, the following: an urban fabric configuration, conditioned by the viral society, where several viruses contaminate its territories, in particular, and currently, COVID-19. Within this urban model, the bodies of social agents are confined to restricted space-times, such as the house.

The causes of such emerging society and city paradigms and the respective social impacts are, for the moment, ambiguous. However, to clarify these phenomena, it is possible now to reflect on a temporal configuration of the viral society that is revealed in the short term, closer and more immediate, that is, the present daily urban life, as announced above. In other words, the text exposed here consists of the outline of a systematic reflection, a possible essay to unveil the singularity of this pandemic. Therefore, it is not a report, partial or total, of a completed research project, but it is still in the preliminary stages of a work in progress.

In such a posture, some preliminary sociological questions are raised, regarding the nature of everyday urban life in the COVID-19 era, mainly in the current conjuncture of multiple mutations of the virus and possible future outbreaks in the global city, which is being transformed, more and more, into a viral city. In particular, critical sociological surveillance of the misunderstandings and even mystifications surrounding this social phenomenon is necessary, given the circumscription of daily life as a mediating reality and concept and a differential instance of the urban subjects and their bodies lives in the city. Indeed, in the same way as leisure at the city, although on a smaller scale, everyday urban life and other configurations of social spatialities and temporalities have been considered "secondary" 
or "residual" problems within some sociological communities. In this way, their social relevance and sociological urgency have been delegitimised. However, this position shows the discomfort of such reflection and the need for a renewed political-scientific resistance to reverse such neglected and stigmatised intelligence and esteem. The present essay seeks to contribute to this sense, undertaking a set of discussions, based on the opinions of several authors, who intend to circumscribe the singularity of the nature of daily urban life, especially in what causes more confusion in some sociological writings that are pronounced, sometimes in an irresponsible way, about the daily life of the city. In fact, it is essentially the complexity of the multiple and nomadic nature of everyday urban life that baffles some authors who are less accustomed to the conflict inherent in this plurality and in the elusive character that underlies daily city and citizenship processes.

In such societal contexts and sociological perspective, the specific objectives of this text are to reflect on two of the conditions and manifestations of sociability within daily urban life: the long-term epochal daily spacetimes (the longue durée, in the words of Fernand Braudel, 1967); the dayto-day space confinements and setbacks caused by COVID-19, in terms of today's viral society and everyday urban viral life.

\section{Methods and Techniques}

The project includes data collection techniques such as interviews and a survey, which are being carried out. Only a few examples of images are presented here, selected from the corpus of sources obtained by direct observation, through photographs and videos, to witness the most relevant facets, especially those that are more concrete and in real-time, related to the viral city. Many of the photos and videos were recorded in the pandemic months corresponding to the first confinement of Portuguese society, since March and April 2020, at Lisbon and at other Portuguese cities or tourist locations, as well as at other countries. These iconic documents and video documentaries are some of the pillars of an iconographic and video collection/archive, compiled by the author for several decades. Such sources portray diverse social and cultural, poetic and aesthetic aspects of historical city realities and more recent scenes of the viral city, inserted in their contemporary social context, the viral society.

Some images and videos of the considered corpus were included in other articles, ebooks and apps manufactured by the author in 2020. For example, an ebook hybridised with an app called Viral Cultural Tourism Via Mobile 
Devices was published as part of this project (Andrade, 2020f). Another ebook hybridised with an app (Andrade, 2020c) includes the "Poem to the Corona Virus: We are all Anti-Virus Viruses", written on April 7, 2020, and using an intermediate methodology called "Pessoa effect", which uses digital heteronyms. These interactive works can be consulted on Mac and Windows platforms or read in epub format. It is possible to download these two ebooks/apps for free, in open access, on the respective sites indicated in the References section.

Several provisional materials corresponding to the project's current and future work in progress are hosted on the following website, whose title is Viral \& Intercultural Cultural City (https://www.sites.google.com/view/ viral-tourism-city).

In addition to this initiative, other manifestations of citizen and cultural resistance to the pandemic at the urban and virtual spaces in the viral city have been organised since March 2020 by various urban and cultural social movements in Lisbon, such as SOS Arte PT, the Museu da Quarentena (Quarantine Museum), the Iminente Festival, the "Efeito Pessoa" (Person Effect) movement, and so forth. It is possible to refer to a collection of sociological analyses on these initiatives and actions founded or co-founded by the author in Andrade (2020a).

The following pages seek to synthesise a historical, sociological and critical reflection on this new viral social reality focused on everyday urban life within the perspective outlined above. The development of debates and case studies on aspects related to the present problem is included in several writings of the author, residing essentially in the University of Minho repository (https://repositorium.sdum.uminho.pt/).

\section{Everyday Urban Life in the History's Longue Durée}

Firstly, consider the main historical diachronic configurations of everyday urban life. The current structured day-to-day life is not similar to the relatively unstructured daily lives in societies prior to the emergence of capitalism and modernity, such as the medieval ones. So, it is convenient to relate daily life to its main historical forms, which is accomplished below (Table 1). 
Table 1 Socio-historical everyday configurations.

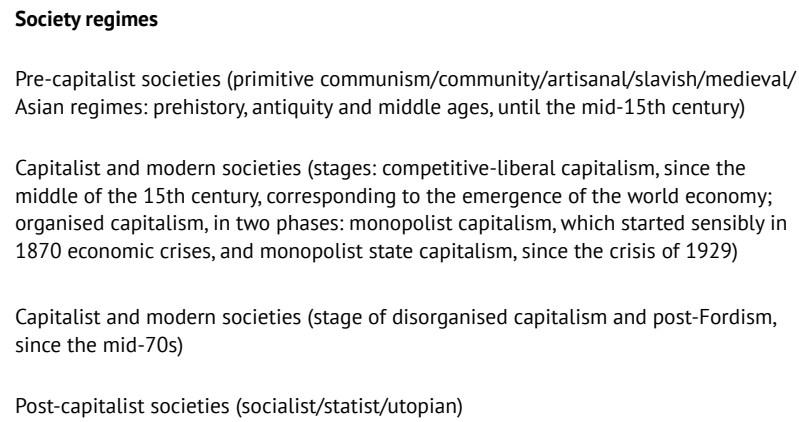

Everyday configurations

Cyclical everyday

Routine everyday

Exceptional everyday

Dialogical everyday

\section{Cyclic Everyday}

In pre-capitalist societal regimes, daily temporalities present themselves in the basic configuration of cyclical every day, although other forms of dayto-day life coexist, less or more deeply. The cyclical daily life is defined as a social time having the following tendency characteristics, which, being partial, are not mutually exclusive: (a) the working day differs little from the daily consumption; (b) the daily life is shown, first of all, like a daily life full of cyclical temporalities, and little associated with leisure, especially that leisure which takes place in spaces and times different from the places and measures regulated by the Gregorian calendar, a model for organising annual Christian festivities, that later served, in part, for the organisation of capitalism production and consumption temporalities; (c) everyday life focuses on the domestic, family and private sphere; and (d) everyday urban life is not markedly different from rural life, except in some major commercial cities, and even so only partially.

\section{Routine Everyday}

The transformations parallel to the rise of capitalism institute a new type of day-to-day life, where the regulation of production and consumption requires parallel control over their daily space-times. Such a rationalisation of life rhythms takes the form of a routine every day that causes widespread alienation and the desire to search for space-time alternatives.

From the 18th century onwards, this new configuration of the everyday emerges, which Fernand Braudel (1967) and other historians have located 
even earlier, partly already in the 16th century. Such a figure is mainly based on the progressive autonomy of social spatialities and temporalities.

In terms of city-country relations, rural locations are gradually being used by the urban bourgeoisie as a resting place instead of work, which is increasingly connected to the urban environment. Secondary residences attest to this new reality, contributing to the sedimentation of holidays as a legitimate activity. A definition of "bodily exercise" in Diderot's Encyclopedia reveals this process: bodily exercise

precisely reflects the emergence of a new opposition between work and non-work: "the meaning of exercise in general is restricted to express the action of the body to which we dedicate ourselves freely and without absolute need, to distinguish it from work". (Barbier, 1981, p. 114)

In a second phase, organised and monopoly capitalism, daily life practices are developed in different social and discursive contexts.

Inside the domestic space, the surfaces increase and rationalise, affecting the rooms of the house to specific uses: in addition to the generalisation of the corridor, which facilitates internal circulation, the compartments specialise, on the one hand, as production and workplaces (e.g., the kitchen), or as privacy places (the bathroom and the bedroom); on the other hand, the house partitions are separated and reorganised spatially and timely, in terms of territories of consumption, leisure, and semi-advertising, such as the dining room and the lounge. Furniture, lighting or blinds add a note of comfort to these semi-privacy configurations.

Within the urban space, more and more specialised places appear within the great divide "workspaces"/"leisure spaces" mentioned above. On the one hand, these localities are directed to a more "active" or playful leisure, such as the places of consumption of beverages, the academies where people play, the reading societies, the clubs and lounges where the conversation is practised. On the other hand, places of "recreation" emerge, with more passive leisure, such as the avenues for public sidewalks and the public gardens. At the same time, the territories more confined to classical culture are intensifying, such as certain painting halls and theatres.

In the field of ideologies and knowledge, new health rules proliferate, such as those related to hygiene, diet and physical education of the body, a more 
and more individual body that influences the social body of the city, and vice versa.

Finally, in the stage of state capitalism, new forms of social segregation are developed, in the background of spaces and daily times: (a) in capitalist societies, in particular, those planned according to economic policies of "creative destruction", a concept popularised by Schumpeter (1994, pp.82-83), which is inspired, albeit somewhat differently, by Marx's previous conceptualisation on capitalist crises; or, (b) partially, in some socialist societies in the initial periods of its implantation. Social classes experience new strategies of distinction in daily life, exhibiting the following characteristics. In pre-capitalist society regimes, there was a kind of private promiscuity, that is, the workplace often coincided with the home, which housed both the family of the possessor of means of production, for example, the artisan, and his employees. In this context, the manifestation of social differentiation was carried out, with more notoriety, in public spaces, through means such as clothing. In modern societies, the opposite happens to some extent: the distinction occurs, in some way, through private spaces, and class promiscuity often becomes public, as in the street, in the square and other collective places of city sociability.

There is a progressive separation between the bourgeois family and their domestic staff in the domestic scene. The latter is gradually located in the production spaces of the house, such as the kitchen, while the head of the family's relatives is restricted to the dining rooms and lounges, which function as places for everyday family free time. The use of the bell to call the servants is an indicator of this social division of space and time. Families that often live under the same roof are being separated territorially through a greater segmentation of the buildings into floors or through the construction of a staircase serving each dwelling resisting as a single common space of the building. Such spatial isolation, contemporary to the social isolation of the different classes, will constitute one of the new forms of alienation of the capitalist city.

Urban housing areas are structured in the dichotomy between a centre and the social periphery. In medieval society, the geographical location was rooted in the profession, and the modern city differentiates its space-times among social classes. In Paris, the wealthy bourgeois and the opulent nobles moved, at the end of the 18th century, to the new neighbourhoods bordering the city, or the north and west. The medieval part of this agglomeration proved to be couture of the nobility, and the eastern part and the 
medieval neighbourhoods in the centre, became bastions of the popular classes, a socio-spatial distribution that is still partially visible today.

In urban public places of social reproduction, there is a notorious proliferation of new places of daily leisure, where strategies of exclusion and social stigmatisation are also manifested. The bourgeoisie abandons corporate parties and taverns and regroup in cafes, restaurants, and generally in spaces more and more private. In some public gardens, access is restricted to the upper classes.

\section{Exceptional Everyday}

In the stage of advanced and post-Fordist capitalism, David Harvey (1990) refers to the compression of social space and times in the last decades of the 20th century. This relationship between temporalities and social spatialities derives, in large part, from the impact of new technologies, which, in the economic sphere, increase production cycles and enable the opening of new markets globally, as happened recently with China. For example, new communication and information technologies, such as the internet or new technologies applied to the tourism industry and services, allow for much more profound profitability of the travel sale and thus greatly reduce the capital's rotation time in that sector.

In this period, the desire to release the constraints of daily routines started in the preceding phase of modern societies progresses through the search for an exceptional every day. In particular, the tourist industry is experiencing significant development, and tourist travel is increasingly spreading to multiple strata of the population. The inhabitants of the central countries gradually become compulsive travellers. Moreover, the natives of the peripheral countries are also transformed into travellers, but essentially as migrants or forced refugees. All these new nomads circulate in spaces where the departure society places overlaps and mixes, more and more, with the places of arrival. The travel time itself hybridises the daily life of the place of origin to the day-to-day of the place of destination. The result is an extraordinary daily life that, in itself and contradictorily, increasingly becomes a routine or a habit, particularly in the daily bodies of urban agents.

\section{Dialogic Daily Life}

As for utopian societal regimes, different interpretations of everyday life, sometimes irreconcilable, may be glimpsed. 
In the case of socialist countries where state regulation prevailed or is maintained, daily life has become instrumental. In other words, the daily rhythms constituted the basis of regulations characteristic of the rationallegal authority, isolated by Max Weber, and that the bureaucracy is the most representative institution. It is the type of authority where administrative and technical procedures replace all other norms, constituting the only form of social legitimation.

However, other less bureaucratic utopian society projects invest in a dialogical daily life, where the day-to-day temporalities are more dialogical but more conflicting, as, by definition, there is no consensus where there is no conflict. One of these dialectics opposes the heterogeneity of everyday life to the homogeneity of broader and more abstract social activities. Georg Lukács (2016) speaks in a kind of daily praxis, the primum, that is, the set of daily behaviours - practical but also theoretical, as the praxis in general - without which neither the construction nor the understanding of human societies is possible. According to Agnès Heller (1970/1977), who is inspired by this author from the Hungarian Marxist school, the characteristic heterogeneity of everyday life also acquires a founding meaning. In fact, day-to-day life provides the necessary experiences for the development of genericity, which means the general, homogeneous and common character that identifies the social activities that structure societies, such as work, science or art. The deliberate use of the primum within daily life contributes to constructing more emancipated social formations, which may be more emancipatory of the individual.

\section{Daily Urban Confinements and Setbacks in the COVID-19 Era}

In today's socio-historical conjuncture, it is urgent to ask the following: what is the nature and what characteristics does everyday urban life have, in the current scene of what seems to emerge as a viral society and, particularly, as a viral everyday urban life?

To answer this question, considering the novelty and uniqueness of such virulent social phenomena, it is necessary to initially formulate general hypotheses from some basic and seminal social dimensions, to test the progressive definition of what can be understood as a viral society. Thus, the present reflection focuses on the spatial-temporal dimensions of the viral society, those that produce and reproduce their daily urban life. In this perspective, the viral everyday acts as an instance of daily mediation 
between two societal dimensions: on the one hand, the social agents that circulate in the city through their bodies or virtually on the internet; and, on the other hand, a set of territories that have also become virulent and that define a viral public sphere, in particular the confined space-times, whether urban or rural.

The precedent circumstance leads to some of the main conditions of urban sociability within these virulent spaces and times. Such daily sociability in the fabric of the city is defined and allowed by state or public health authorities, which function as mediating and regulatory bodies between (a) the social structures of Portuguese society (industries, services, companies, businesses, public health and justice, knowledge, culture, etc.) included in a global world; and (b) the urban social agents, through their bodies and practices in daily life. These agents present concrete social profiles, which, in urban and rural contexts, condition both effectiveness and frequency of confinement/isolation and deflection/displacement practices between the public and private spheres of sociability and socialisation.

\section{Everyday Urban Life Within the Viral Society: 10 Theses}

It is worth noting that there must be an encounter/meeting, with a given possibility and probability, inside a given daily space-time to have urban sociability in everyday life. Alberoni (1990) shows that, in daily life, meaning is produced in encounters, through a continuous movement of differentiation of social actors in their usual space-times:

why is the encounter so important? Because it is a moment of authenticity, because it is the appearance of a meaning. It is the ordering of the multiple, of the disorderly. Small steps are differentiations. We differentiate ourselves internally, just as society objectively differentiates itself with scientific-technical-economic development. (p. 21)

For his part, Pierre Bourdieu (1980) claims that our daily urban life of relationships is made up of incessant appropriations of social capital, that is, the construction of a set of friendships and contacts that we collect in our daily life and that allow us to conquer or to maintain power in a given social field:

social capital is the set of current or potential resources that are linked to the possession of a durable network of more or less institutionalised relations of inter-knowledge and inter-recognition or, 
in other words, to the bonding of a group, as a group of agents that not only are they endowed with common properties (which can be perceived by the observer, by others or by themselves), but they are also united by permanent and useful connections. ( ... ) Exchange transforms things exchanged into signs of recognition. (p. 2)

This daily exchange is carried out in specific places, in institutions that, in their space-time, constitute contexts for welcoming and encouraging sociability practices:

that is why the reproduction of social capital is dependent, on the one hand, on institutions seeking to promote legitimate exchanges and exclude illegitimate ones. They produce events (rallies, cruises, hunts, soirees, receptions, etc.), venues (posh neighbourhoods, elite schools, clubs, etc.) or activities (trendy sports, board games, cultural ceremonies, etc.) which bring together, in a seemingly random way, individuals who are as homogeneous as possible in all respects relevant to the group's existence and persistence. On the other hand, the reproduction of social capital also depends on sociability. That is a continuous series of exchanges in which recognition is continually affirmed and reaffirmed and assumes a specific skill (knowledge of genealogical relations, real connections and art of using them, etc.) and an acquired willingness to obtain and maintain that skill, an expenditure of time and efforts (which have their equivalent in economic capital and also, very often, of economic capital). (Bourdieu, 1980, p. 3)

These and other contemporary authors may help to understand, more profoundly, the social and theoretical field of daily life in the contemporary conjuncture of the coronavirus pandemic, through the following ten theses, among other reflections (Figure 12).

\section{Thesis 1}

Therefore, it is possible to affirm the first following thesis: in the sociohistorical moment of viral aggression by COVID-19, daily urban encounters (Alberoni, 1990) occur essentially in terms of confinement in domestic space-times, which constitute the more symbolic everyday urban life within viral society, in its seminal phase, but not necessarily within the following stages. In this way, the family institution and its most legitimate societal territory, the respective house-home, reproduce themselves socially as 


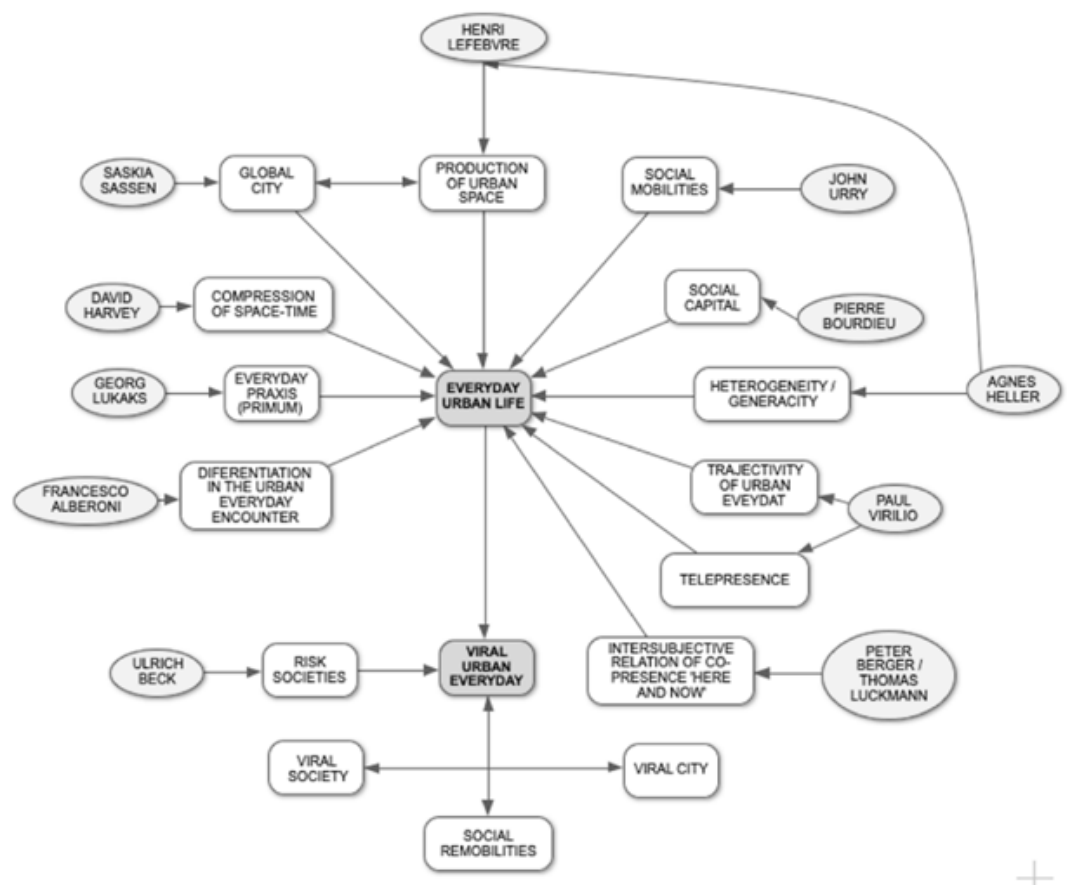

Figure 12 The social and theoretical field of everyday life in the viral society and viral city. Credits. Pedro Andrade

being the context where the different forms of capital (economic, social, cultural, symbolic) allow more significant power games if we apply these concepts from Bourdieu (1980). For example, domestic violence can acquire new intensities in a viral society to perpetuate male power over the female body. This form of power is reinforced by the greater economic capital held by men in a significant number of Portuguese families. Such a condition generates internal inequalities within the space-time of everyday and domestic urban life, and a woman's dependence on her husband or partner, since the woman has to stay even more at home every day, and now for even more hours with her potential abuser.

As for Paul Virilio (1996/2000), he understands our life in the city as a set of journeys/paths, with "trajectivity" being one of the most important everyday properties: 
inscribe the path between the object and the subject and invent the "trajective" neologism to join the "subjective" and "objective" ( ... ) the city is the place of paths and trajectivity. It is the place of closeness between men, of the organisation of contact. Citizenship is the organisation of routes among groups, among men, among sects, etc. (pp. 43-44)

Today, according to Virilio, telepresence completely changes our notions of the space-times of everyday life, of the "here and now" that some subscribers of sociological phenomenologies, such as Peter Berger and Thomas Luckmann (1968), mention. Virilio states (1996/2000): "the question of telepresence relocates the position, the situation of the body. The problem with virtual reality is essentially to deny hic et nunc 'here' for the benefit of 'now' (p. 48).

\section{Thesis 2}

Effectively, such a trajectory seems to be one of the most pertinent features of everyday urban life within viral society. Citizens, before the COVID-19 pandemic, chose certain paths, from their home or work, certainly according to certain macrosocial characteristics, such as the structures incorporated in the bodies of these social subjects (age, gender, urban health, etc.), but also based on microsocial traits, for example, their subjective intentions and daily actions. In addition, the path depends on mediating instances, such as the city and the map of its streets, the location of the usual urban places (home, work, leisure, etc.), or their intrinsic attributes. As a result, a sort of viral telepresence, forced by COVID-19, has dramatically changed citizens' daily lives. In fact, today, COVID-19 has drastically reduced this dialectic between private and public space, contracting the body of social actors to a single and almost exclusive and inclusive space-time, the private house, as noted above. It is worth noting that some of the current "collective houses", or "totalitarian institutions" in the words of Erving Goffman (1961), such as prisons, asylums or homes for the elderly, are not places of salvation from the pandemic but places of serious contamination risk. The hospital itself receives an ambiguous nature. From a healing place, it can easily become a space-time of increased risk for the bodies of urban agents.

\section{Thesis 3}

Daily viral life has a transversal character. It is not confined to a single social sphere but crosses the societal spheres entirely. Thus, there is economic day-to-day of work and leisure, the daily life of politics and powers, or the daily cultural and discursive life. All of them were contaminated by 
COVID-19, whose impact is not limited to the bodies of economic agents but also affects the corporeality of political or cultural actors.

\section{Thesis 4}

In this dimension of social spheres of interest, everyday viral life is different from social reproduction or viral consumption. Agnès Heller (1970/1977), mentioned above, had, for years, opportunely observed, within the Marxistinspired sociology of everyday life, the distinction between those three concepts, in the criticisms, she addressed to her colleague Henri Lefebvre. Like other societal phenomena, the city's daily life, partly based on the production process, presents its own configurations directly related to work. For example, Taylor production chains were alienating, not only because they expressed class domination at the social structural level (the macro social), but also because they reproduced that domination daily, in the repetitive and tedious cycles of the concrete and micro social acts of the labour process over the body of workers. In this way, social reproduction in daily life derives but does not coincide with day-to-day production. The same author also stresses that everyday life should not be reduced to the domestic sphere, where privacy and femininity would prevail, but that it covers both private and public arenas of social life and concerns all social agents. These considerations seem relevant to everyday life in times of coronavirus. Here multiple types of times of production, social reproduction and consumption emerge. New rhythms of teleworking, the unprecedented measures of online consumption, and the new relationships between production and social reproduction in cyberspace allied to cyber time, all of which have somehow prevailed over the physical world of interaction, at least in the first phase of the pandemic.

\section{Thesis 5}

Viral everyday life is constituted, in essence, by social space-times that introduce an intersubjective relationship of co-presence between the social actors in confinement. They correspond to a "here and now", in the words of Peter Berger and Thomas Luckmann (1968). New co-presences emerge in the viral society. For example, a "viral here and now", that is, a being in co-presence (temporal dimension) within a face-to-face relationship (spatial relationship) where the participants do not see the face of this new other due to his mask. In other words, the relationship between masked people during COVID-19 establishes a relationship of identity concealment, which was previously seen as delegitimising and dangerous, restricted to outlaws, or as a connection established and legitimised by religion, such as the burka. 


\section{Thesis 6}

In terms of societal levels' dimension, viral everyday life is not confined to the concrete intersubjective relationships developed by the bodies of social agents in their daily lives. In addition to this micro every day, there is a macro every day and a mediating every day, the latter visible within institutions, organisations, associations and groups that mediate the bodies of social agents with social structures (Andrade, 1991). Today, we are witnessing innovative forms of viral mediating every day, a configuration of daily life that connects two levels of daily life day. On the one hand, the daily practices of the social agents' bodies, in the context of the viral micro every day. For example, the circulation of masked urban bodies, the inter-body social distance, the other body perceived as an aggressor or daily enemy. On the other hand, the viral macro every day is illustrated by industries and services downfall, the liquidation of businesses, or the indefinite and infinite suspension of culture and the arts. Some of the configurations of the viral mediating every day are, in the public space, the streets with areas reserved for circulation; and, in semi-public spaces-times, commercial establishments with waiting times for the assistance of clients and their sociability bodies, a practice sanctioned by the physical barrier at the door, be it a table, a glass or a simple rope.

\section{Thesis 7}

In the context of temporal or diachronic social life, it is simplistic to assume that the viral day-to-day coincides with the routine or is reduced to a cyclical form of existence, experience or consciousness. On the contrary, there are fundamental and historical differences between the everyday routine and the exceptional every day. Moreover, this later day-to-day social form has some similarities with certain types of leisure. In short, within a viral society, the exceptional everyday confinement has become, in some way, an everyday routine.

\section{Thesis 8}

The viral every day is not to be confused, from a temporal/diachronic point of view, with the present. In fact, there is a day-to-day existence in the past and different from the present, as several historians of new history have confirmed. In contemporary viral society, COVID-19 is linked to a past, to other pandemics in history, and a future, the possible COVID-20, COVID-21. 


\section{Thesis 9}

Everyday viral life does not necessarily coincide with the local dimension of urban or rural space-times. In other words, new relations are being established between the local and the global in the era of viral society. For example, in the case of tourists, business people or political leaders, global circulation has been restricted, in part, to multiple local confinements of their societal bodies.

It should also be noted that advanced, disorganised and post-Fordist capitalism engenders what can be understood as a global every day beyond the localised daily life. The collapse of Fordist production caused major changes in the working and consumption models. In addition, this process also influences the production systems of leisure or the production systems of everyday life, especially those more deeply intervening in contemporary societies. Within work activities, post-Fordism caused increased job insecurity, largely due to the advent of new technologies and the consequent need for greater qualification and continuous training. As for daily life and its temporalities, precarious jobs provoke a more irregular organisation of the daily times of working bodies. They become more exposed to overlapping with other temporalities, namely times of leisure. These are made even more indispensable precisely due to the stress caused by the somewhat chaotic nature of the new production rhythms of the latest stage of capitalism or to companies (de)relocation that generates more unemployment.

Such a global/local nature of everyday space-times in recent years means a daily life that is less fragmented by countless places and moments and dependent not only on the spatial accessibility of the means of transport but also on their schedules. This fragmentation was more characteristic of the Fordist period and was caused by a rampant specialisation of activities, parallel to the dispersion of their implantation places and agendas. The phenomenon was quite visible in the places of consumption and leisure where the bodies of urban agents had daily access.

\section{Thesis 10}

Everyday viral life produces and reproduces new individual and social risks in the contemporary city, the viral city. In fact, the current pandemic gives rise to unprecedented uncertainty and risk circumstances, which are much more profound than the times of threats characteristic of the pre-corona virus period. As Ulrich Beck (2013) clarifies, social agents lose their usual 
references to stable orientation points in daily territories and even beyond them within risk societies. In such a context, the personality of social actors is in danger of degrading even more inexorably. The Fordist period was based on social roles of much rigidity that restricted or limited the choice and intervention possibilities and produced, especially in urban metropolises, a kind of alienation founded on loneliness. Apparently, the post-Fordist society allows a wider range of choices.

However, these increased options do not necessarily translate into greater freedom, as the lack of widely agreed criteria for these selections produces, in my view, a situation of continuous doubt and debt about the relevant decisions to be taken. The outcome is an increased individualism, a scattered culture, the omission of truly relevant information and the dismissal of citizenship projects, whether about preserving the past or proposing a dialogue about the future. In short, post-Fordist societies, in addition to other insecurity phenomena, engender even greater and more multiform daily risks.

Thus, a new type of danger, both biological and bodily, economic and social, seems to be emerging, the COVID risk. On the one hand, the coronavirus causes individual health risks in the circulating bodies within the viral city, risks that, for some persons, were less evident at the beginning of the pandemic. However, in the following stages, the pandemic showed the fragility of public health systems more tragically, and in what regards the advances in private health, in the form of private hospitals and pharmaceutical companies founded on unbridled profit, that the competition and runaway to the miraculous anti-COVID vaccine have elicited.

\section{Conclusions}

In such a situation of a viral social pandemic, here are some possible suggestions for alternative practical solutions, among others, to debate and apply within the everyday lives of social actors, aiming the social decontamination of their bodies, in addition to the respective decontamination in terms of collective public health:

- to articulate more deeply the daily space-times of the human bodies activities, among other strategies through the new everyday temporalities inherent to the private spaces of the house, in close connection with the public space-times of work and leisure inside the city, 
- develop communication among the paradigmatic contemporary social agents, such as citizens, tourists and migrants, within the urban public space, for example, through mobile locative devices (Andrade, 2020e), and

- for this purpose, it is also necessary that sociology, like other knowledge, reinvent itself via new research and teaching methodologies, such as sociological cartoons and video papers (Andrade, 2020b).

Such concrete and microscopic everyday tactics can be contextualised inside the global/local networked society in terms of two unprecedented central processes.

The first emerging phenomenon is the viral society, which includes, among other processes, the viral city and the viral bodies of social actors. The detection of their main characteristics in daily urban life was discussed above. Nevertheless, what to do in what regards this seemingly endless pandemic?

The second rising process seeks to overcome the viral society through the "social remobility" strategy. It is understood as a posture to combat societal pandemics, aiming at the alternative recreation of social mobility processes amid contemporary social and communicative processes, such as communication among citizens, tourists and migrants, within their daily urban life. In effect, inside viral society, a social demobility occurs as well. In other words, the mobile society, in which "everything is on the move", as John Urry (2007) referred, has been transformed, in part, into a motionless society. Therefore, it is necessary to de-move it from its i-mobility, through social remobility, among other strategies. Some examples of these social remobilisation processes are urban public arts articulated with mobile cultures, as in the cases of tourist's and digital social networks' cultures. Today, such sociocultural phenomena are founded and merged in virtual-viral communities circulating in cyberspace and cyber time. Moreover, these virtual space-times are understood as conflicting digital public spheres where, at present, pre-viral societies gradually are being deconstructed and rebuilt into post-viral societies.

Translation: Pedro Andrade

\section{Acknowledgements}

This work is supported by national funds through FCT - Fundação para a Ciência e a Tecnologia, I.P., under project UIDB/00736/2020 (base funding) and UIDP/00736/2020 (programmatic funding). 


\section{References}

Alberoni, F. (1990). L'amicizia. Garzanti.

Andrade, P. (1991). A taberna mediática, local reticular de negociações sociais e sociológicas. Revista Crítica de Ciências Sociais, 33, 265-286. http://hdl.handle.net/10316/11715

Andrade, P. (2018a). A cidade interdimensional e as práticas públicas quotidianas. ln H. Pires \& F. Mesquita (Eds.), Publi-cidade e comunicação visual (pp. 103-110). Centro de Estudos de Comunicação e Sociedade. http://hdl.handle.net/1822/55070

Andrade, P. (2018b). Epistemology and methodology of urban cultural tourism: The case of the artistic sociology of mobile cultures and tourism communication in urban social networks. Comunicação e Sociedade, 33, 215-242. https://doi.org/10.17231/comsoc.33(2018).2916

Andrade, P. (2018c). A urbe social e sociológica: Ou a cidade entendida como contexto e enquanto co-texto. In J. Teixeira (Ed.), Espaços, culturas urbanas e contemporaneidade (pp. 41-55). Centro de Estudos Lusíadas.

Andrade, P. (2020a). Cultural resistance to COVID-19: An encyclopedia of public art for artists and tourism publics? Cadernos de Arte Pública, 2, 57-74. http://hdl.handle.net/1822/70084

Andrade, P. (2020b). Cultural tourism and mobile digital devices: An analysis of tourists in Lisbon through sociological comics and video paper. In C. Sarmento \& M. Quincé (Eds.). Intercultural routes across multicultural spaces: From theory to dialogue (pp. 39-56). Centro de Estudos Interculturais. http://hdl.handle.net/1822/70091

Andrade, P. (2020c). Poem on the corona virus using Pessoa effect: An app and ebook anti-virus. Social Web Lab Publishers. https://sites.google.com/view/pedro-de-andrade-art--works/ pessoa-effect

Andrade, P. (2020d). Rua Augusta, um espaço intercultural: Comunicação turística via media locativos para a sustentabilidade territorial. In P. Remoaldo, M.J.Caldeira, V. Teles, E. B. Scalabrini, \& J. A. R. Fernandes (Eds.), Atas do XII congresso da geografia portuguesa: 'Geografias de transição para a sustentabilidade' (pp. 326-331). Universidade do Minho.

Andrade, P. (2020e). Urban public art and tourism communication. Revista Lusófona de Estudos Culturais, 7(1), 39-59. https://doi.org/10.21814/rlec.2119

Andrade, P. (2020f). Viral cultural tourism via mobile devices: Open research using open methods and open media. Social Web Lab Publishers. https://www.sites.google.com/view/viral-tourismcity/home

Barbier, J. (1981). Le quotidien et son économie. CNRS.

Beck, U. (2013). World at risk. Polity Press.

Berger, P., \& Luckmann, T. (1968). The social construction of reality: A treatise in the sociology of knowledge. Open Road Media. 
Bourdieu, P. (1980). Le capital social: Notes provisoires. Actes de la recherche en sciences sociales, 31, 2-3.

Braudel, F. (1967). Civilization matérielle et capitalism: XV ème-XVIII ème siècles. Colin.

Genette, G. (2010). Paratexts: Thresholds of interpretation. Cambridge University Press.

Goffman, E. (1961). Asylums: Essays on the social situation of mental patients and other inmates. Doubleday.

Harvey, D. (1990). The condition of postmodernity: An enquiry into the origins of cultural change. Blackwell.

Heller, A. (1977). Sociologia de la vida cotidiana (J. F. Yvars \& E. P. Nadal, Trans.). Ediciones Peninsula. (Original work published 1970)

Lukács, G. (2016). The destruction of reason. Aakar Books.

Sassen, S. (2001). The global city: New York, London, Tokyo. Princeton University Press.

Schumpeter, J. (1994). Capitalism, socialism and democracy. Routledge. (Original work published 1942)

Urry, J. (2007). Mobilities. Polity Press.

Virilio, P. (2000). Cibermundo: A política do pior (F. Marques, Trans.). Teorema. (Original work published 1996) 


\section{Appendix}

\section{Brief Glossary on Everyday Life Within the Viral City}

Body of social actors: the bodies of the actors involved in daily urban life in the pre-covid-19 era circulated freely inside the urban landscape. Today, these bodies have been transformed, from mediating experience and awareness of the city by social actors to pandemic targets and vehicles for the general contamination of society.

City 3.0 or semantic-social city: globalised locality and configured in an urban socio-geographic network that includes digital social networks and semantic networks characteristics of web 3.0 or semantic web. These social and semantic networks, in addition to information (which constitutes the most frequent type of content on the social networks of web 2.0, e.g., Facebook, Twitter, Instagram), privilege as well knowledge, that is, the explanation or interpretation of information. A typical web 3.0 site is Wikipedia, where non-expert users can share "common concepts" defined by themselves in that area of knowledge (user-generated content).

Creative city: a paradigm of urban space that articulates the city's culture, creativity and transformation. Such a stance highlights, among other processes and practices: interculturalism in the urban fabric, the psychology of the city, creative bureaucracies, and the measurement of creativity inside cities.

Everyday urban life: daily life results from the dialectic between social spatialities and temporalities, which have been transformed throughout history and which condition the present day-to-day. Since the renaissance, the intensification of urban activities has constituted one of the central processes of the epistemological rupture operated by modernity and inaugurated a new articulation between the everyday routine and the everyday exceptional.

Smart City: is a city model that favours planning, monitoring and digital technologies, for greater predictability in urban restructuring, for example, greater mobility and security within the public sphere. However, this ubiquitous visualisation of the city and the citizen carries risks, such as intrusion in his private life, disrespect for human rights, or the naturalisation and uncritical acceptance of widespread panopticism.

Social remobility: it is understood as a posture to fight the viral society, aiming to overcome it and develop alternative recreations of social mobility 
processes amid contemporary social and communicative phenomena, such as communication among citizens, tourists and migrants.

Urban public space: is a paradigm of urban space, where the public dimension of social life acquires relevance and autonomy that differs from private life. This separation and conflict between the public and the private are associated, in economic terms, with the consolidation of commercial and industrial capitalism, coincides politically with the emergence of a democratic society, and is culturally articulated with modernity.

Viral city: is a model of the urban fabric, conditioned by the viral society, where viruses, particularly the current coronavirus, contaminate its territories. In this city genre, the social agents' bodies are confined to restricted space-times, such as the house.

Viral society: is a paradigm based on unprecedented societal processes, e.g., viral economies and technologies, viral politics and politicians, viral cultures and cults. One of the processes that seek to overcome the viral society is social remobility. 